\title{
APPLICATION OF THE SOFTWARE PACKAGE OF ENGINEERING ANALYSIS FOR IMPROVING THE METROLOGICAL ASSURANCE OF HARDNESS MEASUREMENT
}

\author{
ЗАСТОСУВАННЯ ПРОГРАМНОГО ПАКЕТА \\ ІНЖЕНЕРНОГО АНАЛІЗУ ДЛЯ ВДОСКОНАЛЕННЯ \\ МЕТРОЛОГІЧНОГО ЗАБЕЗПЕЧЕННЯ ТВЕРДОМЕТРІЇ
}

V.V. Skliarov,

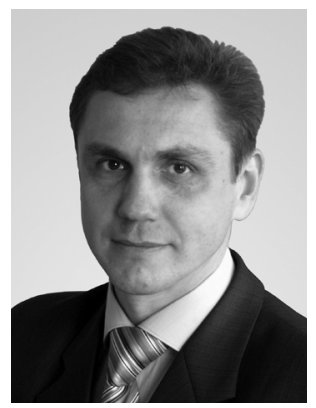

candidate of technical sciences, director of scientific center, scientific secretary of NSC "Institute of Metrology", Kharkiv

The article considers the application of the principle of computational modeling in the construction, improvement and research of the national measurement standards of Ukraine in the field of hardness measurement. The results of modeling research using the finite element method are presented. The methodology of research is proposed in order to improve the characteristics and reduce the uncertainty. The analysis of the further use of computational modeling for the study of components of the national measurement standards is given. The purpose of the article is to improve the research of the measurement standards, particularly, in preparation for international comparisons.

Keywords: computational modeling, finite elements, national measurement standards, hardness measurement, metrological assurance, international comparisons.

Розглядається застосування принципу комп'ютерного моделювання при побудові, вдосконаленні та дослідженні національних еталонів України в галузі твердометрії. Наводяться результати досліджень моделювання з використанням методу кінцевих елементів. Пропонується методологія дослідження з метою поліпшення характеристик та зниження невизначеності. Надається аналіз використання комп'ютерного моделювання для дослідження складових частин національних еталонів. Метою статті $\epsilon$ вдосконалення досліджень еталонів, зокрема, при підготовці до міжнародних звірень.

Ключові слова: комп'ютерне моделювання, кінцеві елементи, національні еталони, вимірювання твердості, метрологічне забезпечення, міжнародні звірення.

\section{Introduction}

According to the Program for the development of the measurement standard base for 2018-2022 [1] and the Law of Ukraine "On Metrology and Metrological Activity" [2], the creation, improvement, maintenance and operation of the national primary measurement standards are the one of the important tasks for economic and scientific and technical development of the country, its defense capability by increasing the level of the uniformity of measurements and metrological traceability from the national measurement standards to measuring instruments used in all branches of the economy, primarily for conformity assessment of the products to the requirements of technical regulations, as well as protection of the citizens and economy from the consequences of inaccurate measurement results.

The National Scientific Centre "Institute of Metrology" (NSC "IM") is the leading metrological organization in Ukraine for ensuring the uniformity of measurements in various branches of the national economy. In NSC "IM", 52 national measurement standards and 16 secondary measurement standards have been created and are operated, which reproduce SI base and derived units. Metrological assurance of the uniformity of measurements in the field of hardness measurement includes the reproduction, maintenance of hardness units by the Rockwell, Super Rockwell, Brinell and Vickers scales, as well as its transfer from the national measurement standards to measuring instruments.

The development of computer technology and computing methods has opened great prospects for the use of finite-element analysis when investigating the hardness measurement problems and the design of modern structures and apparatus.

The principle of the finite-element analysis is in the representation of an object with an infinite number of degrees of freedom, a set of individual finite elements, interconnected in nodal points with a finite number of degrees of freedom. With known physical and mechanical characteristics of an object, the relationship between unknown nodal forces, displacements and influences is determined. As a result, the calculation reduces to the solution of a system with a finite number of linear algebraic equations $[3,4]$. 

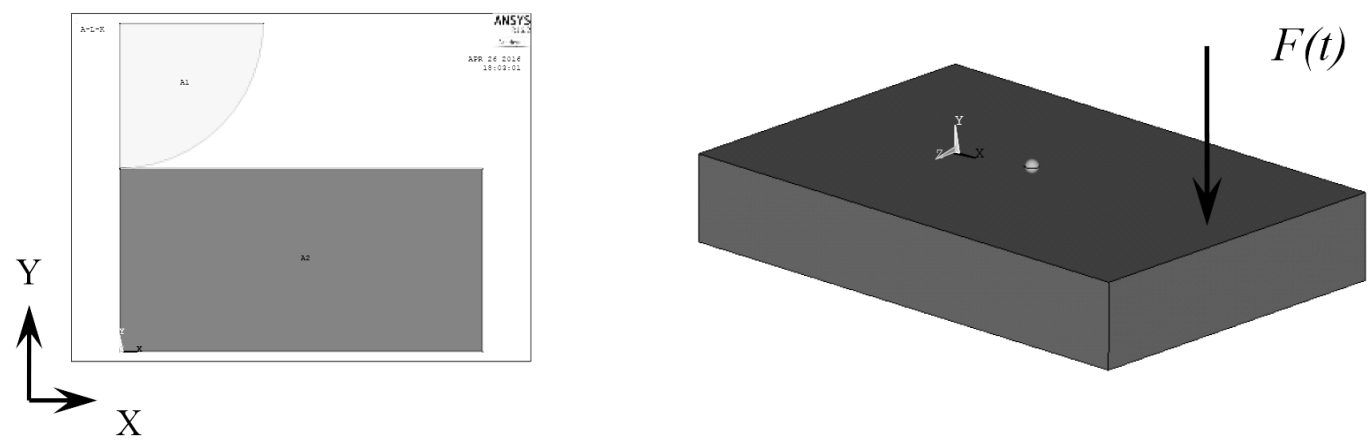

Fig. 1. Geometric indentation model

The use of modern Computer-Aided Engineering (CAE) systems is one of the most effective ways of assessment of the technological processes and complex technical systems. The ANSYS software module (ANSYS, Inc.) is one of the most efficient and most advanced CAE systems. ANSYS is a multi-purpose software package for solving problems of mechanics of a deformed solid body, liquid and gas mechanics, thermal transfer, electromagnetism, and complex problems. The distinctive features of ANSYS are the openness of its programming language (APDL) (ANSYS Parametric Design Language) and the ability to configure it easily for specific tasks and solutions. Use of the internal language of high-level parametric programming allows integrating different calculating elements and solution processes into ANSYS, modifying and supplementing program menus, connecting message files and formulating task solutions in graphical and tabular form or three-dimensional display with a representative color display. ANSYS is the undisputed leader among the "heavy" software packages for automated engineering analysis based on the finite element method.

The ANSYS software product is certified in accordance with a number of international standards and requirements for the nuclear industry.

International standards and requirements: The ISO-9000 series, especially ISO-9001 and ISO 9000-3, Lloyd's Register's software certification, NAFEMS QA certification, British standard BS5750, The TickIT initiative.
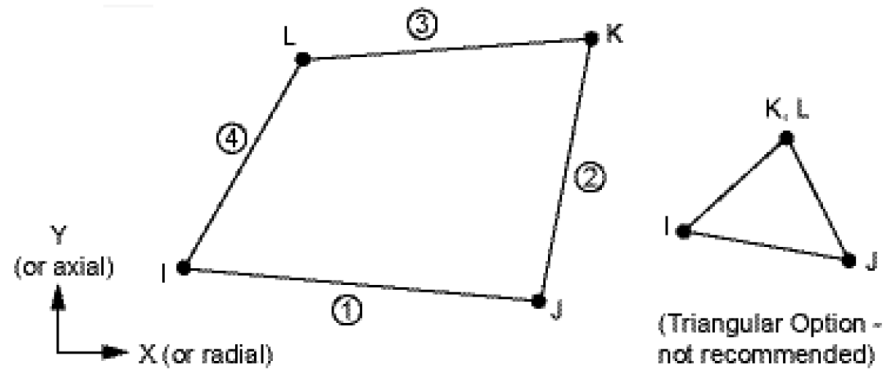

$a-$ PLANE182
American nuclear industry standards: 10CFR50 Appendix B, ASME NQA-1, The ANSI N45.2 series, The ANS/IEEE series of QA and Software Standards, ASME NQA-2, Part 2.7, NUREG/CR-4640 - Hardbook of Software Quality Assurance Techniques Applicable to the nuclear Industry.

\section{The study of the specific features of measurements on the Rockwell and Super Rockwell scales}

The specific feature of the hardness measurement using Rockwell scale is the availability of two types of indenters - spheroconical one (HRA, HRC) and spherical one (HRB scale). Determination of hardness depends on the result of measurement of different parameters, such as load value (for preliminary and total load), the diameter of the spherical indenter, the radius and angle of spheroconical indenter, the penetration depth of the indenter, load application time (for preliminary and total load). The spherical indenter is made of steel or tungsten carbide. The study and comparison of the results of measurements using steel and tungsten carbide indenters are presented in the works [5-7]. These researches were performed taking into account the importance of observing the same conditions in the international comparisons as well as many years of experience in operating the National standard of Rockwell hardness in NSC "IM".

It should be noted that for modelling of a contact problem, the geometry of a spherical indenter

Fig. 2. PLANE182, CONTA 171 and TARGE169 geometry 

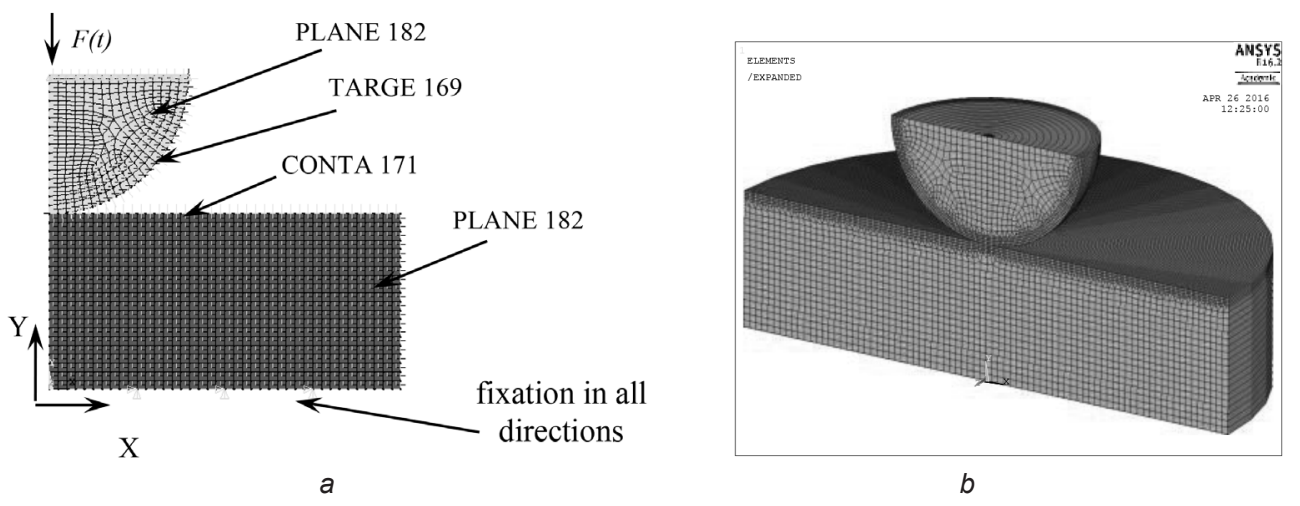

Fig. 3. The finite element model of the contact pair

that is in contact with a specimen can be represented as a two-dimensional axisymmetric model on a plane. This plane passes through the symmetry axis of a spherical indenter and is parallel to one of the faces of the investigated specimen. Thus, in order to reduce the amount of computing resources and increase the rate of solving the contact problem, the geometry of spherical indenter and specimen is performed on the $\mathrm{X}-\mathrm{Y}$ plane (fig. 1). Thereby, $\mathrm{Y}$ axis is both the symmetry axis and the axis of applying the load when indenting.

To create a finite element model, 4-node type of 2-D finite element PLANE182 was used (fig. 2a). To create a contact interaction between the surfaces of two bodies, the contact 2-D elements such as Surface-to-Surface CONTA TARGE171 and 169 were used (fig. $2 b$ ). Requirements for the measurement of hardness by HRB scale are described in [8-10]. In the physical model ANSYS, the force $F(t)$ acts on the indenter, and the specimen is fixed on the bottom surface in all directions. The coefficient of friction between the specimen and a spherical indenter is $\mu=0,1$. Considering the geometric nonlinearities and in order to avoid the weak convergence of the simulation result, the full Newton-Raphson method (tangent lines method) taken into account when writing a software modelling algorithm, was used for the solution of the contact problem [11, 12].

In the given form, the solution of the proposed problem is a classical solution of Henry Hertz problem for a plane surface and a sphere. The classical problem of Henry Hertz found a practical solution for determining the differences in hardness measurements. Using the above-described finite elements, we create a mesh of finite elements for describing research objects. The layout of the contact pair is shown in fig. $3 a$. Given the axisymmetric model, the contact pair can be represented as shown in fig. $3 b$.

Generation of finite element mesh is the most important stage of finite modeling. Using the capabilities of the programming language APDL, we set the size of the finite element to $0,05 \mathrm{~mm}$ (esize, $0,00005,0$ ). Given the axiosymmetry of the investigated objects, the automatic generation of a free-type mesh can be used. Automatic layout of objects is given in fig. $4 a, b$.

Taking into account the small size of the indenter in comparison with the hardness measurement standard (specimen sizes), we assign the condensation of the finite element mesh in the contact location (APDL - amesh, 1,2,1) (fig. 4b).

In this paper, the main purpose of the finite element modeling is the determination of the differences between the three hardness values obtained by steel, tungsten carbide and rigid ball indenters rather than the determination of the hardness of the investigated specimens.

The modeling of the indentation process was performed using the finite element method in the academic version of the ANSYS software product, which is available for free use on the website [13]. Calculations were performed with the material specimens, the characteristics of which are shown in table 1 [14].

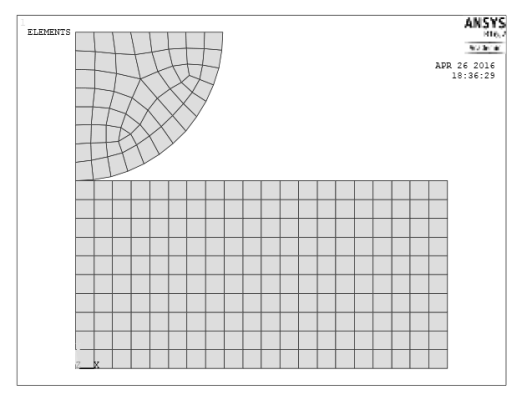

a

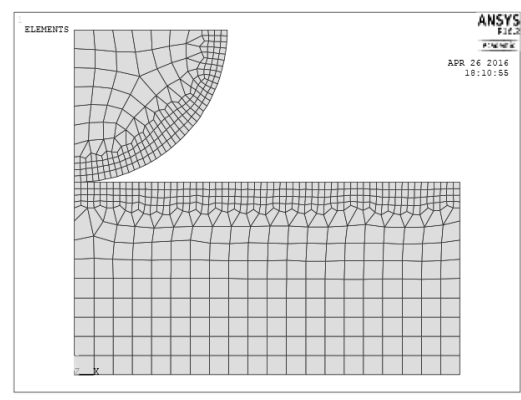

$b$

Fig. 4. Finite element mesh with different condensation 
Table 1

Materials for modeling

\begin{tabular}{|l|c|c|c|c|c|}
\hline \multicolumn{1}{|c|}{ Specimens } & $\begin{array}{c}\text { Hardness } \\
\text { measurement standard }\end{array}$ & Copper M1 & $\begin{array}{c}\text { Aluminum } \\
\text { D16 }\end{array}$ & $\begin{array}{c}\text { Aluminum } \\
\text { B95 }\end{array}$ & Iron 20 \\
\hline European analogue & $\begin{array}{c}\text { AISI 1000 Series } \\
\text { Steel }\end{array}$ & UNS C11000 & $\begin{array}{c}\text { Aluminum } \\
\text { 2024-T 361 }\end{array}$ & $\begin{array}{c}\text { Aluminum } \\
7075-T 73\end{array}$ & AISI 1020 Steel \\
\hline $\begin{array}{l}\text { Hardness on the } \\
\text { Brinell scale, HB }\end{array}$ & $86,0-500$ & - & 130 & 135 & 143 \\
\hline $\begin{array}{l}\text { Hardness on the } \\
\text { Rockwell scale, HRB }\end{array}$ & $49,0-100$ & 35 & 80 & 82 & 78 \\
\hline
\end{tabular}

In order to determine the hardness of the material on the Rockwell scale (HRB), a spherical indenter with a diameter of $1,588 \mathrm{~mm}$ is used as an indenter. To determine the influence of the material of the indenter on the measurement uncertainty of the hardness of the specimen, the modelling was carried out with three different indenters, the mechanical properties of which are presented in table 2 [5].

Table 2

Mechanical properties of indenters

\begin{tabular}{|l|c|c|}
\hline \multicolumn{1}{|c|}{ Indenter } & $\begin{array}{c}\text { Young's } \\
\text { module } \\
\text { E, GPa }\end{array}$ & $\begin{array}{c}\text { Poisson's } \\
\text { ratio, } v\end{array}$ \\
\hline Steel ball indenter & 203,4 & 0,3 \\
\hline Tungsten carbide ball indenter & 633 & 0,22 \\
\hline Rigid ball indenter & $\infty$ & - \\
\hline
\end{tabular}

According to the classical definition, the hardness measurement is performed under the preload and total load. Indentation depth of preload and indentation depth after removal of total load are measured. The difference between the indentation depths $\Delta h=h$ (unloading $)-h$ (loading) is substituted in the formula

$$
H R B=130-\frac{\Delta h(\mathrm{~mm})}{0.002(\mathrm{~mm})}
$$

The relative value $\triangle \mathrm{HRB}$ between steel, tungsten carbide and rigid ball indenters can be calculated by the formula

$$
\Delta H R B=\frac{\Delta \tilde{h}(\mathrm{~mm})}{0.002(\mathrm{~mm})} .
$$

For better representation and analysis, calculated hardness values for different modeling options are given in table 3.

From table 3 it is seen that the maximum and minimum values of hardness were calculated for the steel ball indenter and for the rigid ball indenter, respectively. This effect is due to the greater penetration depth of the steel ball indenter into the specimen due to greater deformation of both the indenter itself and the specimen, which was confirmed experimentally. The calculated hardness values differ by less value than the expanded uncertainty on the Rockwell HRBW scale for the national Rockwell hardness measurement standard [15]. This fact makes it possible to use both steel and carbide-tungsten ball indenters in measurements (comparisons) when using one type of indenter over the entire experiment or comparison.

According to the indentation process, the same differences in the use of steel and carbide tungsten ball indenters exist for the Super Rockwell hardness scale. Steel or carbide tungsten ball indents are used for measurements on HRT, HRW, HRX, HRY scales with different values of the preload and total load on the indenter.

Based on the above methodology, but taking into account formula (3), the modeling and calculations for different thicknesses and types of metal specimens (instrumental steel, copper and aluminum) were performed:

$$
H R T=100-\frac{\Delta h(\mathrm{~mm})}{0.002(\mathrm{~mm})} .
$$

The results are presented in tables 4 and 5 .

Table 3

Results of modeling by the finite element method

\begin{tabular}{|l|c|c|c|c|c|}
\hline \multicolumn{1}{|c|}{ Specimens } & $\begin{array}{c}\text { Hardness for } \\
\text { Steel ball } \\
\text { indenter, HRB }\end{array}$ & $\begin{array}{c}\text { Hardness for } \\
\text { Tungsten carbide } \\
\text { ball indenter, HRB }\end{array}$ & $\begin{array}{c}\text { Hardness for } \\
\text { Rigid ball } \\
\text { indenter, HRB }\end{array}$ & $\begin{array}{c}\text { Differences in hardness } \\
\text { for steel and Rigid ball } \\
\text { indenters, HRB }\end{array}$ & $\begin{array}{c}\text { Expanded } \\
\text { uncertainty, } \\
\text { HRBW }\end{array}$ \\
\hline AISI 1000 Series Steel & 51,965 & 51,908 & 51,778 & 0,187 & 0,253 \\
\hline UNS C11000 & 35,804 & 35,652 & 35,551 & 0,179 & 0,323 \\
\hline Aluminum 2024-T 361 & 81,013 & 80,955 & 80,834 & 0,169 \\
\hline Aluminum 7075-T73 & 82,851 & 82,793 & 82,682 & 0,156 \\
\hline AISI 1020 Steel & 78,371 & 78,342 & 78,215 & \\
\hline
\end{tabular}


Results of modeling by finite element method of specimens of the same thickness

\begin{tabular}{|l|c|c|c|}
\hline \multicolumn{1}{|c|}{ Specimens } & $\begin{array}{c}\text { Measured hardness, } \\
\text { HR30TW }\end{array}$ & $\begin{array}{c}\text { FEM simulation hardness, } \\
\text { HR30TW, see in table 5 }\end{array}$ & Difference (\%) \\
\hline Superficial-Rockwell hardness reference block & 76,0 & $\mathbf{7 7 , 1 2 1}$ & 1,45 \\
\hline UNS C11000, 10 mm & 67,4 & $\mathbf{6 5 , 7 6 3}$ & $-2,42$ \\
\hline Aluminum 2024-T 361, 10 mm & 82,3 & $\mathbf{8 0 , 4 8 3}$ & $-2,20$ \\
\hline AISI 1020 Series Steel, $10 \mathrm{~mm}$ & 72,6 & $\mathbf{7 6 , 6 7 1}$ & 5,30 \\
\hline
\end{tabular}

Table 5

Results of modeling by finite element method of specimens of the different thickness

\begin{tabular}{|c|c|c|c|c|c|}
\hline Specimens & $\begin{array}{l}\text { Hardness for } \\
\text { Steel ball } \\
\text { indenter, } \\
\text { HR30T }\end{array}$ & $\begin{array}{l}\text { Hardness for } \\
\text { Tungsten carbide } \\
\text { ball indenter, } \\
\text { HR30TW }\end{array}$ & $\begin{array}{l}\text { Hardness for } \\
\text { Rigid ball } \\
\text { indenter }\end{array}$ & $\begin{array}{l}\text { Differences in } \\
\text { hardness for } \\
\text { steel and Rigid } \\
\text { ball indenters }\end{array}$ & \multirow[t]{2}{*}{$\begin{array}{c}\text { Expanded } \\
\text { uncertainty, } \\
76 \pm 6 \\
\text { HR30TW }\end{array}$} \\
\hline & \multicolumn{4}{|c|}{ AISI 1000 Series Steel, only 6 mm } & \\
\hline $\begin{array}{l}\text { Superficial-Rockwell } \\
\text { hardness reference block }\end{array}$ & 77,338 & 77,121 & 77,032 & 0,306 & \multirow{13}{*}{0,715} \\
\hline Thickness, mm & \multicolumn{4}{|c|}{ UNS C11000 } & \\
\hline 1,5 & 73,362 & 72,859 & 72,747 & 0,615 & \\
\hline 2,0 & 70,432 & 70,102 & 70,020 & 0,412 & \\
\hline 10,0 & 65,996 & 65,763 & 65,649 & 0,347 & \\
\hline Thickness, $\mathrm{mm}$ & \multicolumn{4}{|c|}{ Aluminum 2024-T 361} & \\
\hline 1,5 & 85,779 & 85,328 & 85,097 & 0,682 & \\
\hline 2,0 & 83,832 & 83,520 & 83,346 & 0,486 & \\
\hline 10,0 & 80,794 & 80,483 & 80,338 & 0,456 & \\
\hline Thickness, $\mathrm{mm}$ & \multicolumn{4}{|c|}{ AISI 1020 Series Steel } & \\
\hline 1,5 & 81,328 & 80,908 & 80,724 & 0,604 & \\
\hline 2,0 & 79,751 & 79,268 & 79,112 & 0,639 & \\
\hline 10,0 & 77,019 & 76,671 & 76,496 & 0,523 & \\
\hline
\end{tabular}

As in measurements on the Rockwell scale, and according to tables 4 and 5, the maximum and minimum hardness values were calculated for the steel ball indenter and for the rigid ball indenter, respectively [16]. This fact allows to use in measurements (comparisons) on the Super Rockwell hardness scale both steel and carbide tungsten ball indenters when using one type of indenter over the entire experiment or comparison.

\section{Modeling of the mounting frame for the measurement standard on Vickers scale}

To eliminate the impact of the "frame effect" when loading the indenter, the national measurement standards of many COOMET and EURAMET countries use a direct load on the indenter.

We will consider the use of a mathematical apparatus in improving the installation of hardness measurement on the Vickers scale, which is described in [17].

The machine consists of a direct load mechanism for creating test forces and a control unit, which allows setting all the most important parameters involved in the measurement cycle. The structure of the measuring installation is shown in fig. 5 [18].

Load support system E is used to reproduce the required load values for obtaining the required test loads HV $(10 \mathrm{H}, 20 \mathrm{~N}, 30 \mathrm{~N}, 50 \mathrm{H}, 100 \mathrm{H}$ and $120 \mathrm{~N})$. This system includes the frame of the indenter and the weighting device. The loading and unloading system $G$ provides selection of loads. To allow the strictly vertical load by the direct load mechanism, a fixing frame $M$ is used. The fixing frame should be sufficiently rigid to withstand bending or deflection due to the applied compression load. Load analysis was done by the finite element method. Fig. 6 shows the modeling of the load of the indenter frame $(a)$ and the fixing frame $(b)$.

The analysis of the modeling results allows to conclude that the influence of the stress of the direct load system on the measurement process is absent. Moreover, mismatch factor $\mathrm{E}_{\mathrm{n}}$ obtained from the key comparison of the Vickers Hardness measurement standard, which belongs to the National Institute of Standards of Egypt, with the national measurement standard of PTB, confirms the correctness of the performed calculations and the construction of the direct load system [18].

\section{Modeling of measurements on the Brinell scale}

According to the conventional definition, the hardness on the Brinell scale is calculated by the formula (4) [19] 

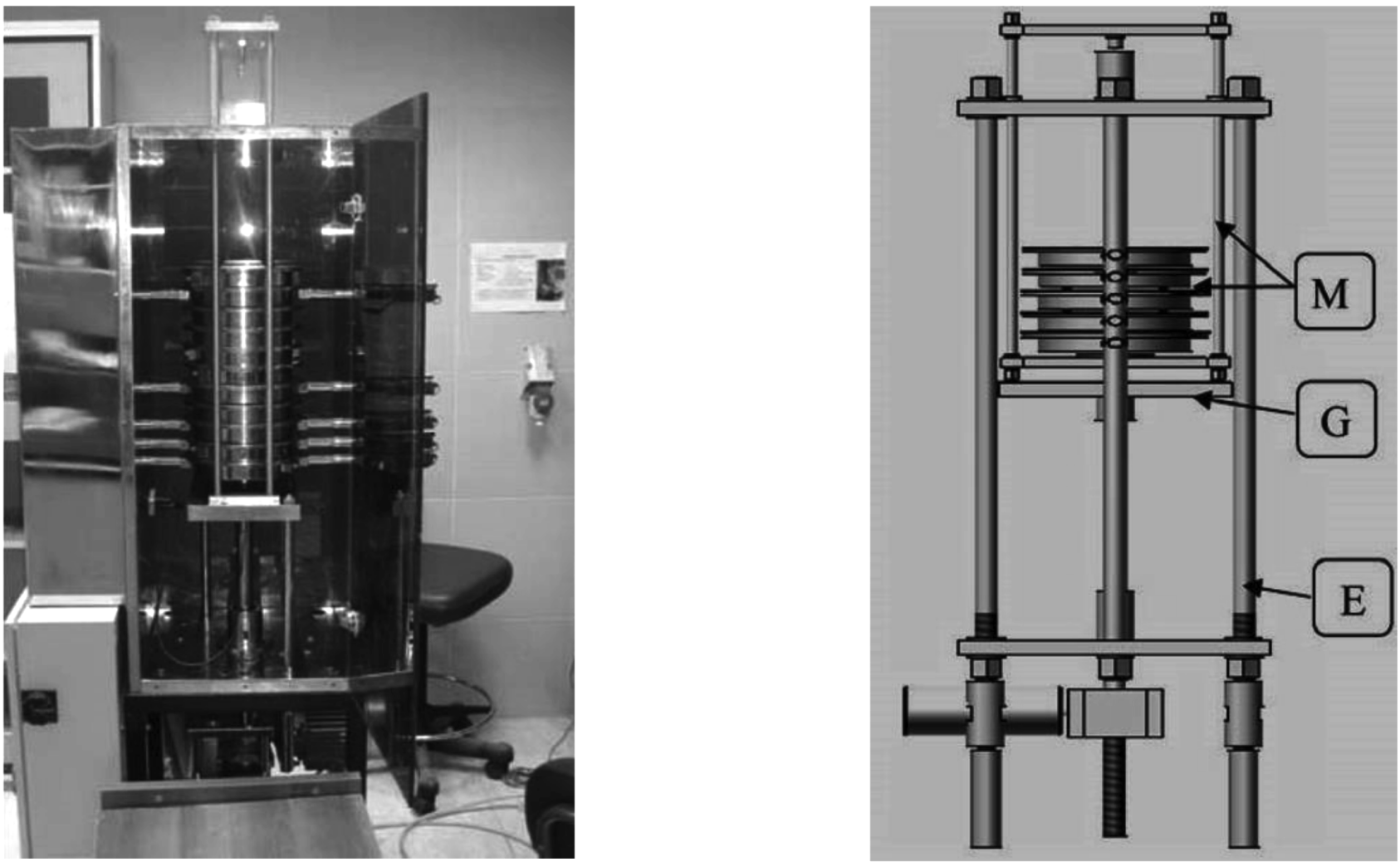

Fig. 5. The system of direct load

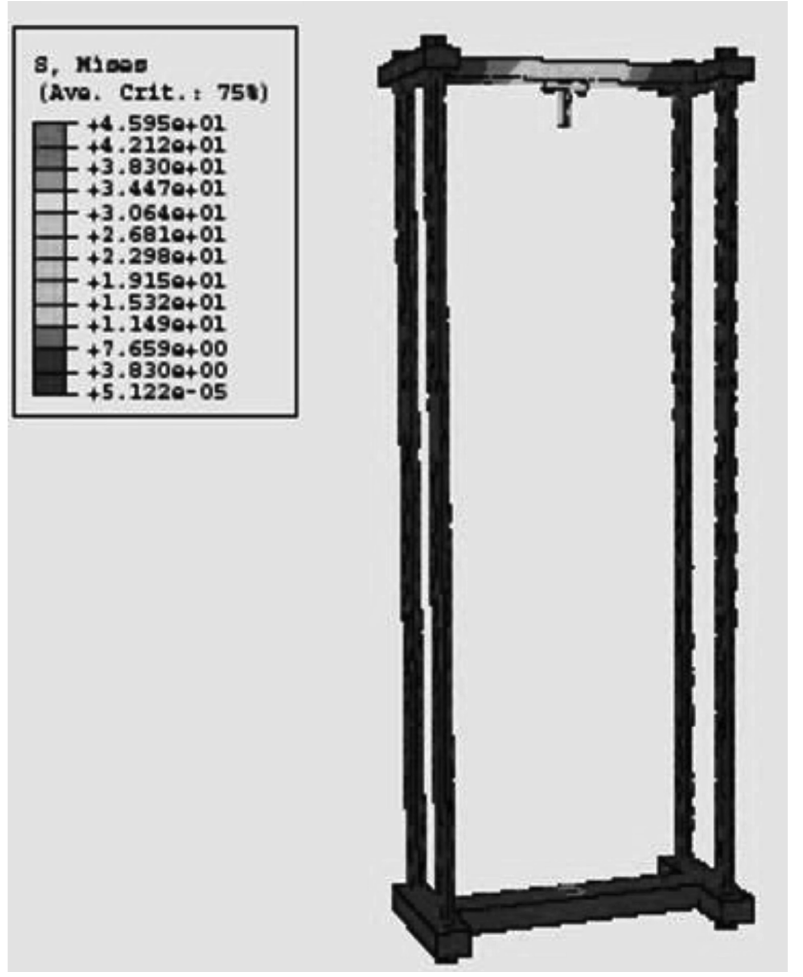

a
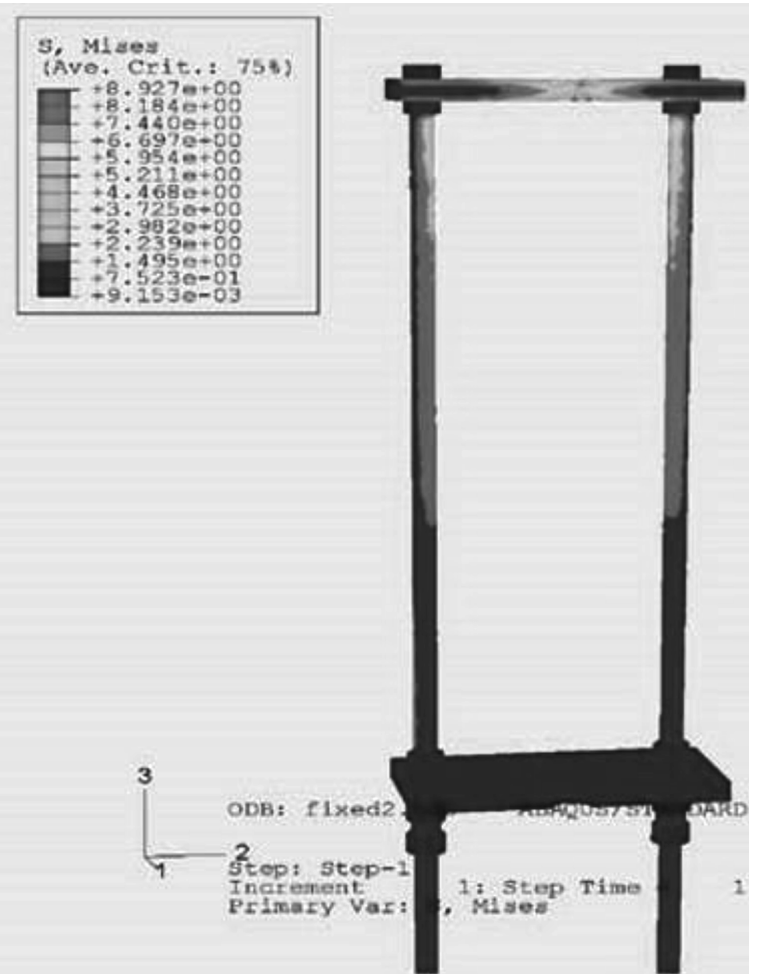

$b$

Fig. 6. Modeling of direct load system

$$
H_{\mathrm{B}}=\frac{F}{D \cdot\left(D-\sqrt{D^{2}-d^{2}}\right) \cdot \frac{\pi}{2}} \text {, }
$$

where $F$ - load force from $5 \mathrm{kN}$ to $30 \mathrm{kN}$, according to the type of material, which acts within 30 seconds;
$D$ - diameter of the steel ball indenter and $d$ - indentation diameter on the surface of the examined specimen (see fig. 7).

One of the most common building materials is concrete. One of the methods for determining the hardness of concrete is the Brinell method. For modeling the hardness of concrete, a discrete element method is used, which re- 


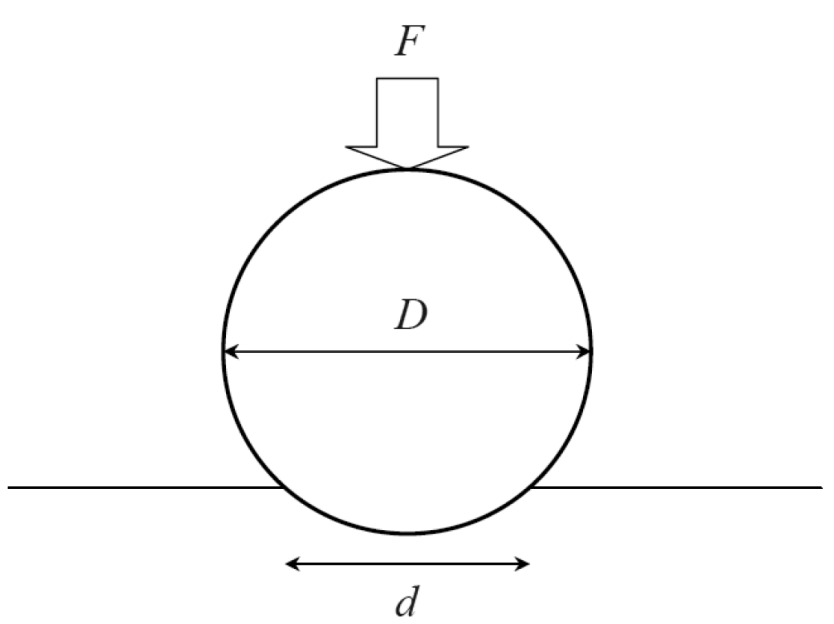

Fig. 7. Scheme of measurements on the Brinell scale

flects the behavior of porous solid materials when indenting using spherical body. The discrete element method is a tool for the modeling of porous solid materials such as concrete, which allows visualizing the internal movements in material that are generated during the test. The method helps to observe and understand behavior of the material and to determine its hardness.

During the numerical modeling, a steel sphere with a diameter of $10 \mathrm{~mm}$ was penetrated into the surface of a cubic concrete specimen. The steel sphere was modeled as a separate body (fig. 8) [20].

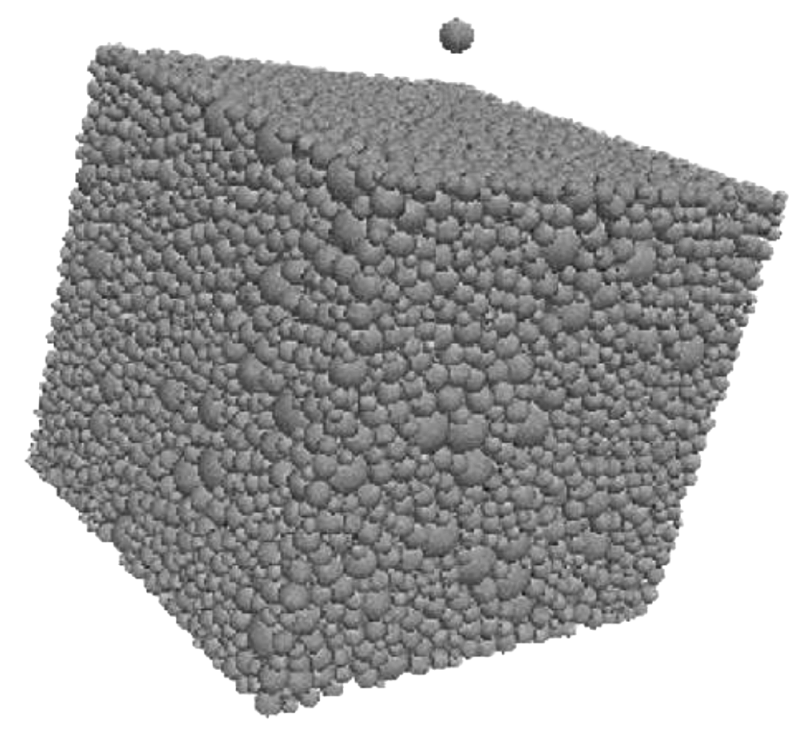

Fig. 8. Model of a concrete specimen with a steel indenter

The rigidity of the steel body (indenter) is much higher than the rigidity of the concrete specimen. In this case, the discrete elements are considered spherical and completely rigid, therefore deformations of the material can be obtained from the contact forces. The contacts between the particles are modeled with parallel connections, which provide the behavior of the particle displacement in the material. These connections establish an elastic interaction between the particles, which acts simultaneously with the sliding forces or with the contact forces.
Concrete was modeled by a large number of discrete elements (particles). The size of the discrete element distribution in the concrete model was the same as the particle size distribution in real material. In the model, the particle size distribution of real material was accompanied by the determination of the particle size. For the analysis of the modeling results, the obtained values of the deformation diameters of the concrete specimen were compared with the results of the conducted laboratory research. The results of comparisons of indentation areas are shown in fig. 9 [20].

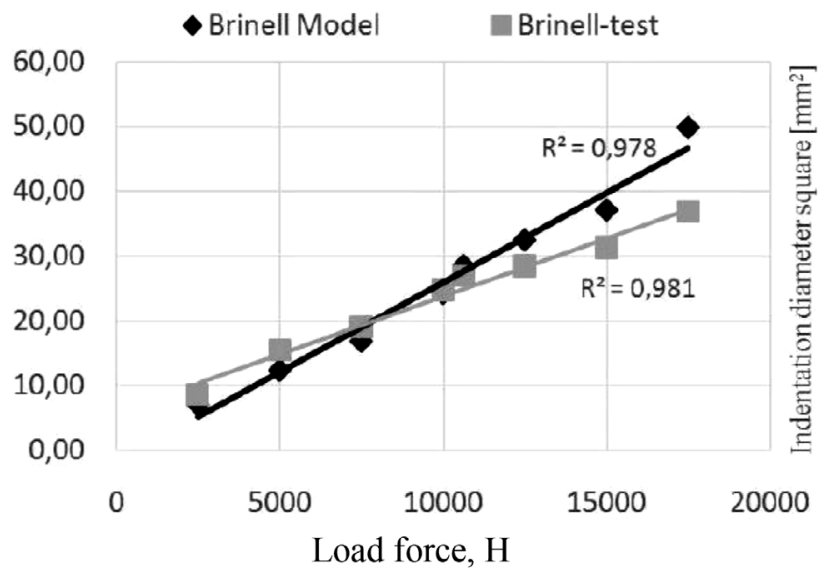

Fig. 9. The results of modeling and laboratory research

The ratio between the indentation diameter $\left(\mathrm{mm}^{2}\right)$ and the load force $(\mathrm{H})$ is linear. The correlation coefficient of results exceeds $0,97(97 \%)$. If the correlation coefficient is above $95 \%$ then the results can be considered statistically significant.

According to the results of the research, it is obvious that the hardness of the concrete can be modeled using the developed model, especially at medium loads. The developed model provides the adequate modeling of the laboratory results and allows to analyze numerically the hardness of the investigated specimen [20].

\section{Modeling of the relation between the stress state of the body and hardness}

Plastic strain of metal significantly changes its internal structure and affects many of its mechanical, physical and chemical properties. In the process of plastic strain, electrical resistance increases, magnetic properties change and thermal conductivity and metal strength decreases. This effect is noticeable when measuring the hardness of a strained body, which is associated directly with the increase in the strength of the material, its hardness.

Using the possibilities of the finite element method and ANSYS Academic, an input file was created in the APDL programming language, the content of which reflects: the construction of geometry, taking into account the type of finite elements and material properties, a clear partitioning into the finite elements, boundary 


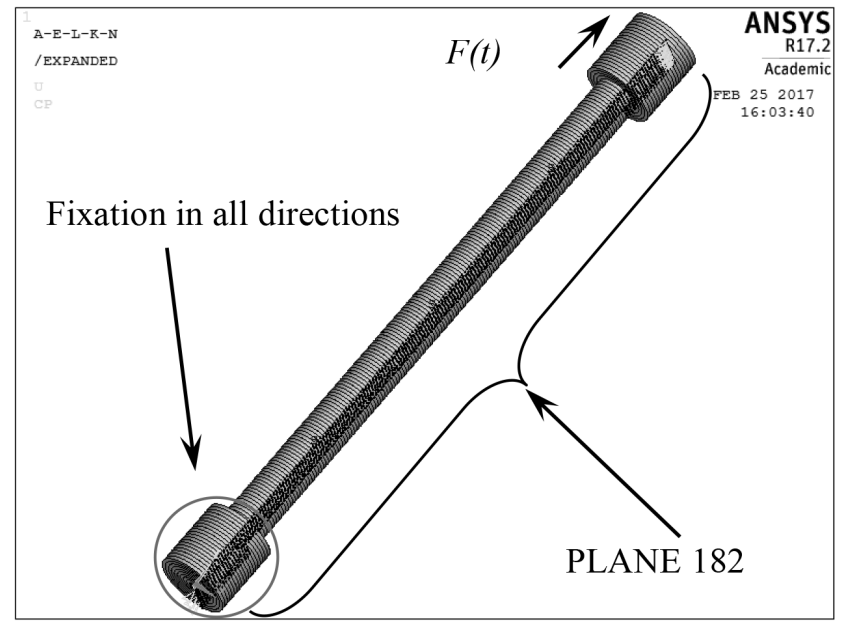

a

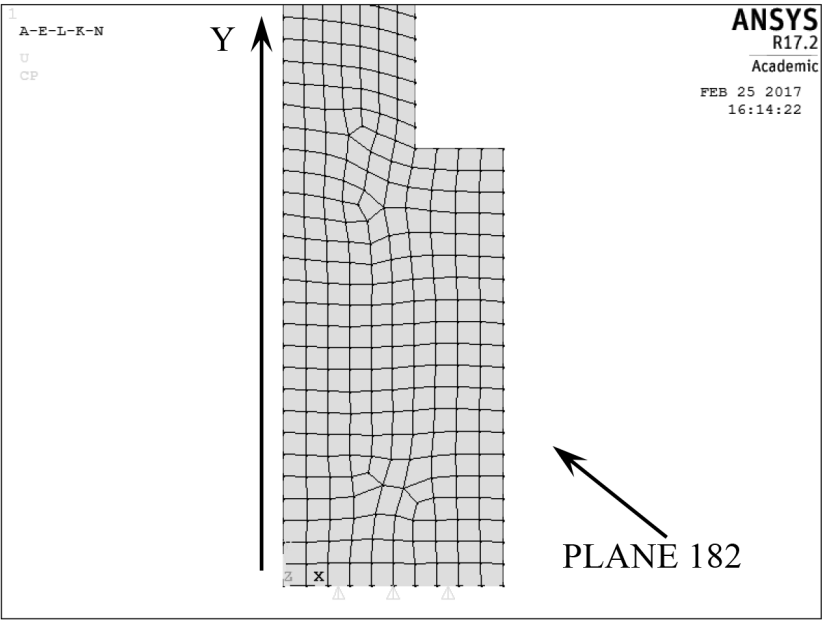

$b$

Fig. 10. The geometric model of a specimen with finite element mesh

Table 6

Relation of stress zones with hardness

\begin{tabular}{|l|c|c|c|c|c|c|c|c|}
\hline Check point & 1 & 2 & 3 & 4 & 5 & 6 & 7 & 8 \\
\hline Distance from rupture zone, mm & 3 & 5 & 7 & 10 & 15 & 20 & 25 & 30 \\
\hline Diameter after rupturing, mm & 4,5 & 4,6 & 4,8 & 5,2 & 5,3 & 5,5 & 5,7 & 6 \\
\hline Hardness in check point, HRB & 61 & 59 & 57 & 55 & 52 & 51 & 50 & 49 \\
\hline von Mises stress, MPa & 194,6 & 143,5 & 141,6 & 141,6 & 141,6 & 141,6 & 141,6 & 141,6 \\
\hline von Mises plastic strain, MPa & 0,069 & 0,066 & 0,063 & 0,062 & 0,061 & 0,061 & 0,061 & 0,061 \\
\hline
\end{tabular}

conditions and options for establishing the solution. To reduce the amount of computational resources and increase the speed of the solution, the geometry of the specimen is presented as a two-dimensional axisymmetric model.

To generate a finite element model of objects, the 4-node type of 2-D finite element PLANE182 was used. Using the above-mentioned finite elements, an automatic coupling of the body with a given $0,5 \mathrm{~mm}$ finite element was performed (fig. 10). As a result, 1612 finite elements and 1827 nodes were created in the mesh [21].

Table 6 shows the dependence of the von Mises stress zone and the von Mises plastic strain due to hardness at eight check points located along the whole length of the specimen after the rupture.

The results of modeling the von Mises stress and the von Mises plastic strain are shown in fig. $11 a, b$.
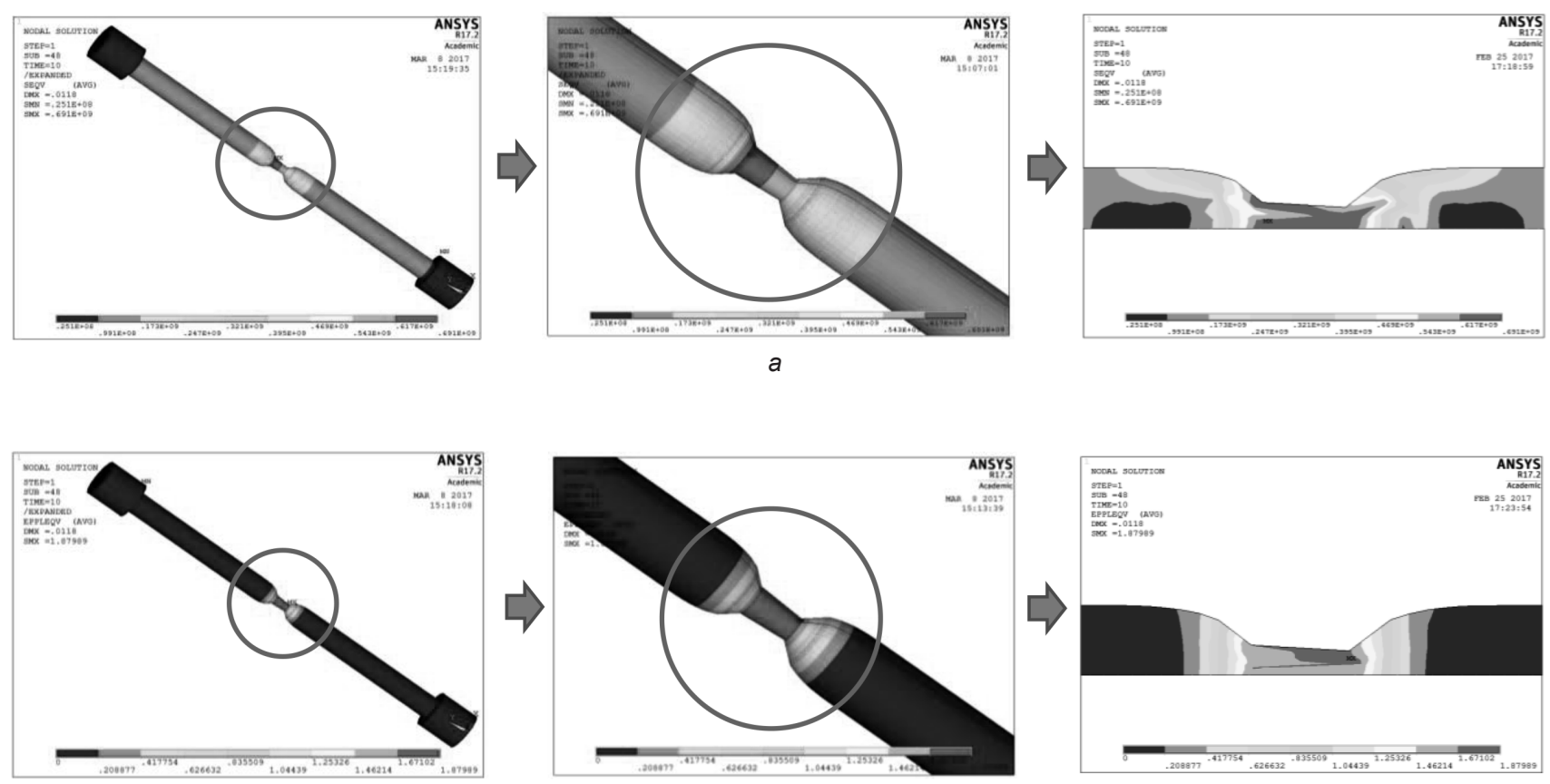

Fig. 11. The modeling of the von Mises stress (a) and the von Mises plastic strain $(b)$ 
The results of experimental studies and finite element modeling allowed to establish a connection between the stress-strain state of the material and the hardness of the surface. It was found that when the stress intensity was changed by $61,2 \%$, the hardness was changed by $17,4 \%$. As a result of the modeling, it was found that the maximum hardness value in the plastic strain zone did not exceed $69 \mathrm{HRB}$, which corresponds to the von Mises stress intensity of $366 \mathrm{MPa}$. The phenomenological connection between the calculated and experimental values of hardness and the stress state of the specimen was determined. The results obtained are important for assessing the results of international comparisons of the national hardness standards. Taking into account the results of the assessment and prediction of the hardness of the first class standard hardness specimens in their production are the prospects of practical application.

\section{Finite element analysis in prediction of mechanical properties}

At the present stage of development of engineering thought and additive technologies, materials science has entered into the period of new possibilities for design and manufacture of elements, introducing of the new methods of melting, molding, forming and heat treatment. Modern materials shall have high mechanical, physical, chemical, as well as technological properties to ensure its long and reliable use.

One of the most widespread materials with high technological characteristics are materials based on magnesium alloys and coatings - MCMgAl12Zn1, MCMgAl6Zn1, MCMgAl3Zn1 and MCMgAl9Zn1. Magnesium alloys and their derivatives are characterized by low density $\left(1,5-1,8 \mathrm{~g} / \mathrm{cm}^{3}\right)$ and high strength in relation to their weight $[22,23]$.

To evaluate the hardness of specimens with magnesium coating, modeling using the ANSYS software package and comparison of the results with the results of experimental studies were performed. As in the case of modeling the hardness measurement on the Rockwell scale, it was taken into account that the model is symmetric, so in order to reduce the calculation time, $1 / 4$ part of the real model of the indenter and the specimen with sputter was calculated. The initial load was $98.1 \mathrm{~N}$ and the total load was $588 \mathrm{~N}$. The modeling was carried out with finite elements of type SOLID95 and CONTA 174. SOLID95 finite element is used for three-dimensional modeling of solid structures. It is determined by twenty nods, each of which has three translational degrees of freedom (UX, UY, UZ) and properties of materials (elastic modulus, Poisson's ratio, thickness, thermal state coefficient). The element automatically takes the global coordinate system. CONTA 174 final element was used to determine the contact between the specimen and the indenter. This element is located on the surface of the rigid body and is determined by eight nodes. In addition, to provide the connection of SOLID95 finite element mesh with CONTA 174, MESH 200 finite element was used that has the properties of a solid material and simulates a non-deformed solid substance. This element is only a connecting mesh and is not included in the calculations. A variable number of finite elements was used to avoid errors in calculations. In locations where high deformation gradients were expected, the grid was thicker than in locations where deformation was absent. That is, the condensation of the finite element mesh was made in the location of contact. Based on the obtained modeling results it was possible to calculate the theoretical hardness, which corresponds to the experimental results (table 7) [24].

Table 7

Comparison of modeling results and experimental tests

\begin{tabular}{|ccc|}
\hline & \multicolumn{2}{c|}{ Alloys MCMgAl12Zn1 } \\
\hline & As-cast & after aging \\
\hline $\begin{array}{c}\text { Rockwell } \\
\text { hardness tests }\end{array}$ & 75.380 & 94.600 \\
\hline $\begin{array}{c}\text { Computer } \\
\text { simulations }\end{array}$ & 74.2 & 102.3 \\
\hline $\begin{array}{c}\text { Rockwell } \\
\text { hardness tests }\end{array}$ & 65.680 & 75.140 \\
\hline $\begin{array}{c}\text { Computer } \\
\text { simulations }\end{array}$ & 62.5 & 76.8 \\
\hline $\begin{array}{c}\text { Rockwell } \\
\text { hardness tests }\end{array}$ & 51.940 & Alloys MCMgAl6Zn1 \\
\hline $\begin{array}{c}\text { Computer } \\
\text { iymulations }\end{array}$ & 54.3 & 53.200 \\
\hline $\begin{array}{c}\text { Rockwell } \\
\text { hardness tests }\end{array}$ & 30.640 & 31.500 \\
\hline $\begin{array}{c}\text { Computer } \\
\text { simulations }\end{array}$ & 32.6 & 36.8 \\
\hline
\end{tabular}

Thus, the finite element method is an ideal tool for solving the scientific and applied problem of predicting and calculating the hardness of structural materials with pre-known technical and operational properties without complex and expensive experiment. As a practical application, presented methodology can be used in calculating the hardness models of materials with known mechanical characteristics and evaluating the results of comparisons for COOMET and EMPIR projects.

\section{Conclusions}

The finite element method and software packages of engineering analysis are now widely used in such fields of science as mechanics, biomechanics, mechatronics, mechanical engineering and thermodynamics. Software engineering packages reduce the design pro- 
cess and provide an opportunity to explore individual factors that affect the whole model. The finite element method makes it possible to understand the relations between the various parameters of the measurement process, allows choosing the optimal solution by the criterion of the minimum value of the measurement uncertainty.

Based the performed research, an explanation of the difference of the indentation depths for the steel spherical indenter and the tungsten carbide spherical indenter was found when performing the research on the Rockwell and Super Rockwell hardness scales. The hardness quantities differ by values that are within the expanded uncertainty for the Rockwell and Super Rockwell national measurement standard. The obtained values are confirmed by the results of experimental measurements carried out on the national measurement standard of hardness DETU02-04-99. The results obtained have significant importance for assessing the results of international comparisons of the national measurement standards.

Investigation of the constructive characteristics of the loading system of the national measurement standard on the Vickers hardness scale allows reducing the effect on the expanded uncertainty of such a component of the uncertainty budget as the impact of the frame effect when applying load to the indenter (deformation of frame). It also allows carrying out research in the field of micro-hardness measurements, which is important in the determination and investigation of hardness of different technological coatings and sputters.

As prospective directions for further research and practical application, it is intended to use the finite element method and software packages of engineering analysis in the investigation, improvement and creation of the national measurement standards of Ukraine.

The author expresses his sincere gratitude to V. Bolshakov, Doctor of Technical Sciences, Senior Researcher, Honored Scientist and Technician of Ukraine, COOMET Honored Metrologist, Vice-President of the Academy of Metrology of Ukraine, O. Prokopov, Doctor of Physical and Mathematical Sciences, Professor, and Ye. Timofeyev, Doctor of Technical Sciences, Senior Researcher, for discussions and advice when structuring and writing this paper.

\section{References}

1. "Program for the development of the measurement standard base for 2018-2022" No. 1041 of December 28, 2016, available at: http://zakon2.rada.gov. ua/laws/show/1041-2016-\%D0 \%BF

2. Law of Ukraine "On Metrology and Metrological Activity" dated June 5, 2014 No. 1314-VII, available at: http://zakon2.rada.gov.ua/laws/show/1314-18

3. Zenkevich O.S. Finite Element Method in Engineering. M.: Mir, 1975. 349 p.
4. Finite element method in solid state mechanics, ed. A. Sakharov and I. Altenbach. Kiev: Higher school; Leipzig: Feb Fahbuhferlag, 1982. 420 p.

5. Ma L., Low S., Song J. "Comparison of Rockwell B hardness (HRB) tests using steel and tungsten carbide ball indenters" Proceeding of IMEKO TC3 / TC5/TC20-2002-022.

6. Low S. R., Pitchure D. J. and Flanigan C. D. "The Effect of Suggested Changes to the Rockwell Hardness Test Method". Proceeding of 16th World Congress of International Measurement Confederation (IMEKO-XVI). Austria, Sept., 2000.

7. Ma L., Low S., and Fink J. "Effects of Steel and Tungsten Carbide Ball Indenters on Rockwell Hardness Measurements". Journal of Testing and Evaluation, 2006. Vol. 34. No. 3, pp. 1-13, http://dx.doi.org/10.1520/JTE100048. ISSN00903973.

8. ISO 6508-1. Metallic Materials - Rockwell hardness test (scale A, B, C, D, E, F, G, H, K, N, T). Part 1: Test method. Geneva: International Organization for Standardization, 2005.

9. ISO 6508-2. Metallic Materials - Rockwell hardness test (scale A, B, C, D, E, F, G, H, K, N, T). Part 2: Verification and calibration of the tasting machine, Geneva: International Organization for Standardization, 2005.

10. ISO 6508-3:2005. Metallic Materials-Rockwell hardness test. Part 3: Calibration of reference blocks. Geneva: International Organization for Standardization, 2005.

11. Kabanov Y. The contact technology in the action, ANSYS Solution. Russian version, Autumn 2007, pp. $5-10$.

12. Lukyanova A. N. Modeling of the axisymmetric contact problem using the ANSYS [electronic edition] of Lab. work. Samara: Samara State Techn. University, 2014. $52 \mathrm{p}$.

13. Webpage: http://news.plm-ural.ru/20082015-715

14. Webpage: http://www.matweb.com

15. Skliarov V., Zalohin M. Comparison and analysis of steel and tungsten carbide Rockwell B hardness ball indenters utilizing a general purpose finite element approach. SCIT 2016, System, Control and Information technology 20-21.05.2016 Warsaw, Poland. DOI: 10.1007/978-3-319-48923-0_71

16. Skliarov V., Zalohin M., Dovzhenco J. FEM simulation and experimental measurement of hardness by the Superficial Rockwell HRT scale using the steel and tungsten carbide spherical indenters. Proceeding of Smart Structures NDE, 25-28 March 2017, Portland, Oregon, USA. DOI: 10.1117/12.2257352

17. Mohamed G. Design and construction of primary Vickers hardness testing machine M. sc. thesis presented to Cairo university, faculty of engineering, May 2009.

18. Menalo F., Mohamed G., Mohamed M. I., Abuelezz A.A., Adly M., Khatab A.A. Develop- 
ment of Primary Vickers Hardness Testing Machine. IMEKO 2010 TC3, TC5 and TC22 Conferences Metrology in Modern Context 22-25 November 2010, Pattaya, Chonburi, Thailand.

19. Tabor D. The hardness and strength of metals. Journal of the Institute of Metals, 79:1-18, 951.

20. Gyurkó Z., Borosnyói A. Brinell-hardness testing and Discrete Element Modelling of hardened concrete. Journal of Silicate Based and Composite Materials, 2015, Vol. 67, No. 1, pp. 8-11, http://dx.doi.org/10.14382/epitoanyag-jsbcm.2015.2

21. Skliarov V. Application of the FEM for modeling and prediction of the relationship between the hardness and stress of the deformed body. Proceeding of Smart Structures NDE, 25-28 March 2017, Portland, Oregon, USA. DOI: $10.1117 / 12.2258370$
22. Baker H. Physical properties of magnesium and magnesium alloys. The Dow Chemical Company, Midland, 1997.

23. Chuang C.H., Huang J.C., Hsieh P. J. Using friction stir processing to fabricate $\mathrm{MgAlZn}$ intermetallic alloys, Scripta Materialia 53 (2005), pp. $1455-1460$.

24. Dobrzański L.A., Śliwa A., Tański T. Finite Element Method application for modelling of mechanical properties. Archives of Computational Materials Science and Surface Engineering 1/1 (2009), pp. 25-28.

Статтю рекомендовано до публікаиї доктором технічних наук, професором Ю.Ф. Павленко.

The article is recommended for publication by Yu. F. Pavlenko, Doctor of Technical Sciences, Professor. 